\title{
Glu298Asp, -786T $>C$, and Intron 4 a/b Polymorphisms of Endothelial Nitric Oxide Synthase Gene in Behçet's Disease
}

\author{
Behçet Hastalığında Endoteliyal Nitrik Oksit Sentaz Geni Glu298Asp, -786T>C ve \\ İntron $4 \mathrm{a} / \mathrm{b}$ Polimorfizmleri
}

\author{
Remin AKÇAY TAN, ${ }^{1}$ Halil Gürhan KARABULUT, ${ }^{2}$ Ayşe BOYVAT, ${ }^{3}$ Işık BÖKESOY \\ ${ }^{1}$ Department of Genetic Diagnosis Center, Alman Hospital, İstanbul, Turkey; \\ ${ }^{2}$ Department of Medical Genetics, Medical Faculty of Ankara University, Ankara, Turkey; \\ ${ }^{3}$ Department of Dermatology, Medical Faculty of Ankara University, Ankara, Turkey
}

\begin{abstract}
Objectives: In this study, we investigated the relationship between endothelial nitric oxide synthase (eNOS) gene polymorphisms and predisposition to Behçet's disease.

Patients and methods: One hundred and fifty-five unrelated patients (69 males, 86 females; mean age 40.5 years; range 14 to 66 years) and 98 healthy controls (43 males, 55 females; mean age 34.2 years; range 17 to 78 years) were examined for eNOS gene Glu298Asp, $-786 \mathrm{~T}>\mathrm{C}$ and intron $4 \mathrm{a} / \mathrm{b}$ polymorphisms.
\end{abstract}

Results: The GG genotype in the Glu298Asp polymorphism was found to be significantly higher in the patient group $(p=0.02)$. The TT genotype in the -789 T $>C$ polymorphism was found to be more prevalent in the control group $(p<0.001)$. The distribution of the intron $4 \mathrm{a} / \mathrm{b}$ polymorphism and allele frequencies did not differ significantly between the two groups.

Conclusion: In our study, the -786T>C polymorphism was found to be correlated with Behçet's disease, irrespective of family history, age at onset of the disease, or clinical findings. The $\mathrm{C}$ allele was found to be more prevalent in patients with Behçet's disease. The intron $4 \mathrm{a} / \mathrm{b}$ and Glu298Asp polymorphisms were not found to be directly related to the disease.

Key words: Behçet's disease/diagnosis/etiology/genetics; nitric oxide synthase; polymorphisms.
Amaç: Bu çalışmada endoteliyal nitrik oksit sentaz (eNOS) geni polimorfizmleri ile Behçet hastalığına yatkınlık arasındaki ilişki araştırıldı.

Hastalar ve yöntemler: Akrabalık ilişkisi olmayan 155 hasta (69 erkek, 86 kadın; ort. yaş 40.5 yıl; dağılım 14-66 yıl) ve 98 sağlıklı kontrolde (43 erkek, 55 kadın; ort. yaş 34.2 yıl; dağılım 17-78 yıl) eNOS geni Glu298Asp, -786T>C ve intron $4 \mathrm{a} / \mathrm{b}$ polimorfizmleri incelendi.

Bulgular: Glu298Asp polimorfizminde GG genotipinin, hasta grubunda anlamlı ölçüde yüksek olduğu saptandı $(p=0.02)$. $-789 \mathrm{~T}>C$ polimorfizminde ise TT genotipi kontrol grubunda daha yaygın olarak bulundu $(p<0.001)$. Intron $4 \mathrm{a} / \mathrm{b}$ polimorfizminin dağılımı ve alel frekansları açısından iki grup arasında anlamlı fark bulunmadı.

Sonuç: Çalışmamızda, aile öyküsü, hastalığın başlangıç yaşı veya klinik bulgulardan bağımsız olarak, -786T>C polimorfizminin Behçet hastalığı ile ilişkili olduğu gösterilmiştir. C aleli Behçet hastalığı olanlarda daha yaygın olarak bulundu. Intron $4 \mathrm{a} / \mathrm{b}$ ve Glu298Asp polimorfizmleri hastalıkla doğrudan ilişkili bulunmadı.

Anahtar sözcükler: Behçet hastalığı/tanı/etyoloji/genetik; nitrik oksit sentaz; polimorfizmler.

\footnotetext{
Received: August 25, 2010 Accepted: November 21, 2010

Correspondence: Remin Akçay Tan, M.D., PhD. Alman Hastanesi, Genetik Hastalıklar Tanı Merkezi, 34433 Taksim, İstanbul, Turkey.

Tel: +90 212 - 2932150 e-mail: akcayremin@yahoo.com

C2011 Turkish League Against Rheumatism. All rights reserved.
} 
Prof. Dr. Hulusi Behçet first defined Behçet's disease in 1937 as a triad of recurrent oral aphthous ulcerations, genital ulcerations, and iridocyclitis. Today, Behçet's disease is considered as a multisystemic vasculitis with vascular, articular, gastrointestinal, pulmonary, and neurological involvement. The etiology still remains obscure, and the clinical course is characterized by exacerbations and remissions of unpredictable duration and frequency. ${ }^{[1]}$ The geographic distribution of disease is typical, and it is especially prevalent between $30^{\circ}-45^{\circ}$ northern latitudes. Turkey reportedly has the highest prevalence with a frequency of occurrence recorded as $80-420 / 100000$. Behçet's disease affects male and female patients equally but tends to run a more severe course in males. ${ }^{[2]}$ The age of patients at onset generally falls within the second and third decades. It is rarely seen in children and adults above 50 years of age. Most of the cases are sporadic, but familial accumulation can be seen in endemic regions. The rate of intrafamilial occurrence is given as 2-3\%; however, this rate could reach $10-15 \%$ in Middle Eastern countries. In juvenile patients, familial accumulation is more common. The prevalence of isolated manifestations of the disease is also higher in the first-degree relatives of patients..$^{[1,3-6]}$

In individuals with genetic predisposition, immunoregulatory disorders due to certain microbial agents were suggested to be the cause of multisystemic involvement. ${ }^{[1,6]}$ Increased superoxide and lysosomal enzyme production is seen in neutrophils of patients with Behçet's disease. In addition to marked neutrophil infiltration observed in mucocutaneous aphthous ulcers, pathergy reactions, nodular skin, and ocular lesions increase at the serum levels of some neutrophil activator cytokines, and mediators released from activated neutrophils were observed. There are publications indicating a correlation between increased neutrophilic function and HLA-B51. Lymphocyte dysfunction in patients with Behçet's disease is also reported. ${ }^{[6-11]}$

The presence of autoantibodies against oxidatively modified low density lipoproteins and increased prostacycline levels suggests endothelial dysfunction. Detection of higher serum plasminogen activatorinhibitor 1, von Willebrandt factor, thromboxane, and thrombomodulin concentrations are indicators hinting at the presence of endothelial dysfunction. Endothelial damage leads to autooxidative damage and higher levels of oxygen radicals. It is known that in cases with Behçet's disease, pro-oxidant levels in circulation increase, and neutrophils especially produce higher levels of free oxygen radicals. ${ }^{[4,8,12-14]}$ Nitric oxide (NO) has been implicated in the inflammatory reaction in Behçet's disease. ${ }^{[15]}$ However, some literature indicates decreased levels of NO, particularly during the active phase of the disease in the same patients. ${ }^{[12,16]}$ The investigators who found decreased $\mathrm{NO}$ levels state that NO metabolites originating from inducible nitric oxide synthase (iNOS) released from neutrophils could have resulted in the increased levels of NO found in some studies. Since NO release at baseline causes local vasodilatation, inhibition of platelet aggregation, and proliferation of smooth muscle cells, decreased levels of NO can be easily taught to result in endothelial dysfunction due to an irregularity in NO release process. Already, literature reporting endothelial dysfunction in patients with Behçet's disease is available. ${ }^{[17,18]}$

The human endothelial nitric oxide synthase (eNOS) gene maps to 7q35-36. It is $21 \mathrm{~kb}$ in size and involves 26 exons. The gene encodes an messenger ribonucleic acid (mRNA) of 4052 nucleotides. Its predicted weight is $133 \mathrm{kDa}$. After a demonstration of the eNOS sequence, numerous variations in the promoter region, exons, and introns have been detected. When searching for the variants influencing enzymatic functions, it has been revealed that $786 \mathrm{~T}>\mathrm{C}$ on the gene's 5 ' flanking region due to the presence of a cytosine nucleotide instead of thymine at -786 nucleotide position reduced promoter activity resulting in lower enzymatic activity. Also, the activity was decreased due to faster RNA trimming via Glu298Asp (due to the presence of guanine instead of the thymine nucleotide at the gene's 894 . nucleotide position) localized at exon 7 . In addition, contrary to the results of the investigation performed by Wang et al. ${ }^{[19]}$ in 1997, a study conducted by Tsukada et al. ${ }^{[20]}$ in 1998 reported the carriage of the 'a' allele in intron 4 (4 repeats of repetitive sequences with 27 bp localized in intron 4) was said to decrease serum NO levels. However, Wang et al. ${ }^{[21]}$ published the results of their investigation in 2000 which elucidated the matter and stated that despite decreases in serum levels of eNOS mRNA and protein, enzymatic activity was found to be increased, and disregarding the evidence relating to the lowering effect of cigarette smoking on enzymatic activity in selected individuals could have had an impact on results which were obtained by other investigators. ${ }^{[19-25]}$

The role of endothelial dysfunction in Behçet's disease has been recognized, and some studies have demonstrated a decrease in levels of circulatory NO in Behçet's disease. Certain polymorphisms of the eNOS gene have been shown to decrease the activity of the enzyme. Taking into account all of this information, 
investigation of the relationship between eNOS gene polymorphisms and predisposition to Behçet's disease was intended in this study.

\section{PATIENTS AND METHODS}

Study group: This study was carried out in 155 unrelated patients (69 males, 86 females; mean age 40.5 years; range 14 to 66 years) referred to the Multidisciplinary Behçet's Disease Unit at Ankara University, Faculty of Medicine with the diagnosis of Behçet's disease established according to diagnostic criteria of the International Behçet's Disease Study Group. Age and gender were matched in the eligible 98 healthy control subjects ( 43 males, 55 females; mean age 34.2 years; range 17 to 78 years). The patients and the controls were enrolled in the study after obtaining their informed consents and after the approval of the ethics committee of the University. Clinical findings of the patients were learned from their files. Deoxyribonucleic acid (DNA) extracts of all samples were obtained using the standard salt extraction method. Analyses of polymorphisms were performed in compliance with previously defined polymerase chain reaction (PCR) settings..$^{[1,26,27]}$

The level of the significance of the data acquired was sought with the aid of SPSS for Windows version 15.0 software (SPSS Inc., Chicago, Illinois, USA) using a chi-square test. $\mathrm{P}<0,05$ was considered as statistically significant.

\section{RESULTS}

The $-786 \mathrm{~T}>\mathrm{C}$ mutation could be studied in only 91 control subjects. The mean age at diagnosis was 30.4 years. Eighteen out of 86 patients who were interrogated had positive familial history. All clinical findings of 107 patients examined are summarized in table 1.

The gel sample for the Glu298Asp polymorphism is seen in figure $1.248 \mathrm{bp}$ is the mutant allele while the

\begin{tabular}{|lcc|}
\hline Table 1. Clinical findings & & \\
\hline Clinical findings & \multicolumn{2}{l|}{ Positive finding } \\
\cline { 2 - 3 } & $\mathrm{n}$ & $\%$ \\
\hline Pathergy & $42 / 94$ & 44.6 \\
Mucocutaneus & $107 / 107$ & 100 \\
Eye & $43 / 118^{*}$ & 36.4 \\
Articular & $32 / 107$ & 29.9 \\
Vascular & $20 / 107$ & 18.6 \\
Gastrointestinal & $6 / 107$ & 5.6 \\
Neurological & $6 / 107$ & 5.6 \\
\hline *: There were 11 patients whose clinical & findings, except & for \\
involvement, were not previously known. \\
\hline
\end{tabular}

presence of 163 and $85 \mathrm{bp}$ fragments represent the wild type. The gel sample for the $-786 \mathrm{~T}>\mathrm{C}$ polymorphism is shown in figure 2. 155 and $82 \mathrm{bp}$ fragments are normal alleles whereas fragments 155,46 , and $36 \mathrm{bp}$ represent mutant alleles. The gel appearance of the polymorphism in intron 4 is seen in figure 3. Allele ' $b$ ' is 454 bp with five repeats; allele ' $a$ ' is 427 bp with four repeats.

The genotypes and allele frequencies of the eNOS gene polymorphisms of the control and patient groups are given in table 2. The GG genotype in the Glu298Asp polymorphism observed in the patient group was significantly higher $(p=0.02)$. The frequency of the $\mathrm{G}$ allele was also significantly higher $(\mathrm{p}=0.011)$. As for the $-789 \mathrm{~T}>\mathrm{C}$, the TT genotype was found to be

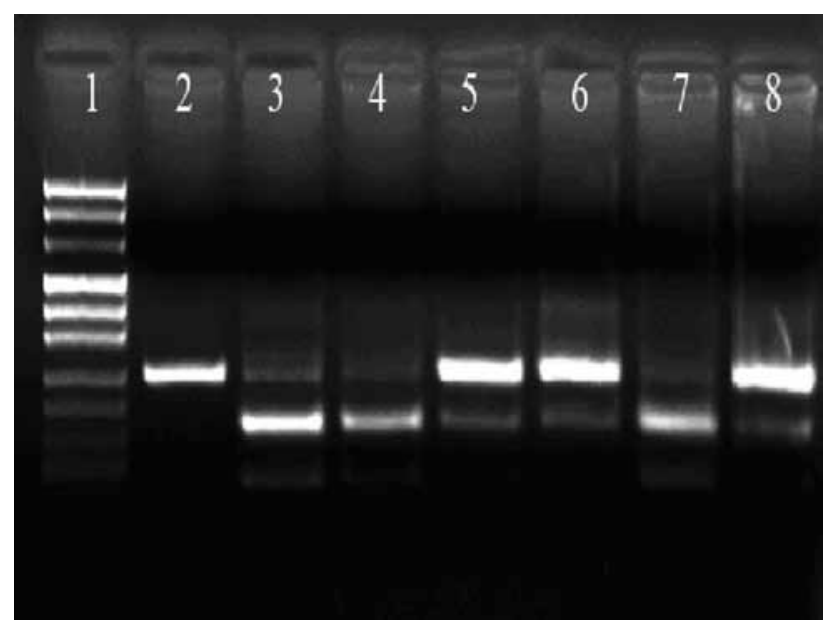

Figure 1. Gel sample for Glu298Asp polymorphism: the $1^{\text {st }}$ lane is the marker; the $2^{\text {nd }}$ is TT; the $3^{\text {rd }}, 4^{\text {th }}$, and $7^{\text {th }}$ lanes are GG; the $5^{\text {th }}, 6^{\text {th }}$, and $8^{\text {th }}$ lanes are GT.

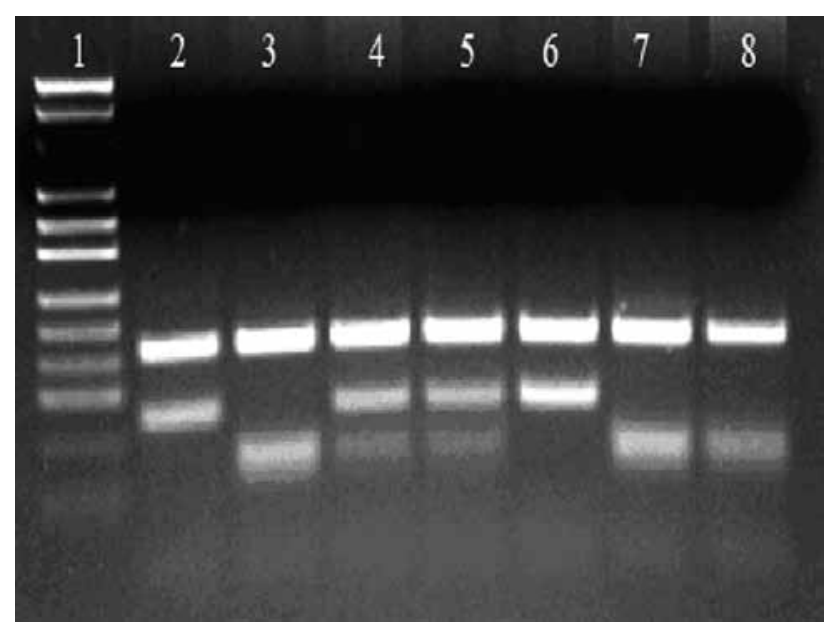

Figure 2. Gel sample for $-786 \mathrm{~T}>\mathrm{C}$ polymorphism: the $1^{\text {st }}$ lane is the marker; the $2^{\text {nd }}$ and $6^{\text {th }}$ lanes are TT; the $3^{\text {th }}, 7^{\text {th }}$, and $8^{\text {th }}$ lanes are CC; the $4^{\text {th }}$ and $5^{\text {th }}$ lanes are TC. 


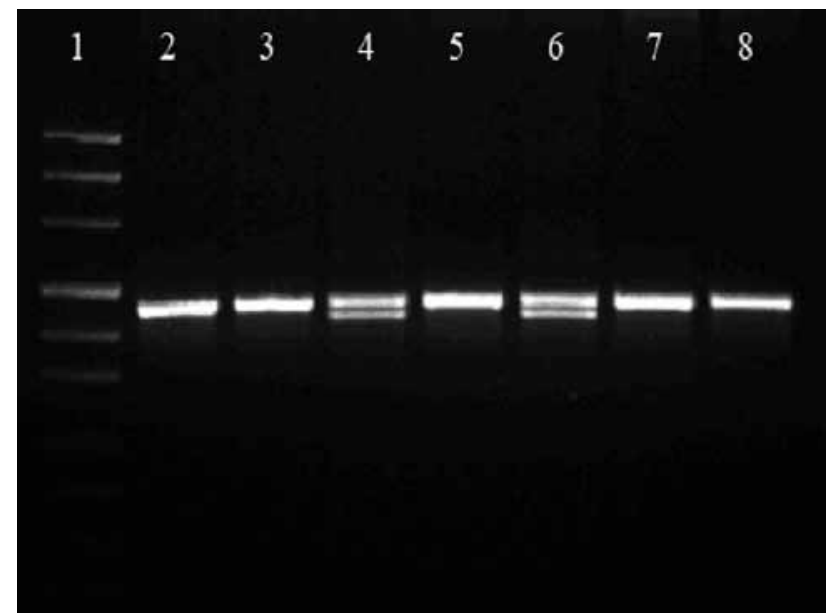

Figure 3. Gel appearance of polymorphism in intron 4: the $1^{\text {st }}$ lane is the marker; the $4^{\text {th }}$ and $6^{\text {th }}$ lanes are ba; the other lanes are bb.

more prevalent in the control group $(\mathrm{p}<0.001)$. The $\mathrm{T}$ allele frequency was also higher with a $\mathrm{p}<0.001$. The distribution of the $\mathrm{a} / \mathrm{b}$ polymorphism and allele frequencies did not differ significantly between the two groups ( $\mathrm{p}=0.159$ and $\mathrm{p}=0.453$, respectively).

In addition to this assessment, the following results were obtained from comparisons performed between the patient and control groups regarding age at onset of the disease, clinical findings, and familial history:

The aforementioned frequencies did not change with regard to estimates related to the age of onset. Patients whose ages at onset were under or over 30 years were compared both within the same group and with the controls whose ages were younger than 30 years. For intragroup comparisons among patients, $p$ values for the Glu298Asp, -786T $>C$, and intron $4 \mathrm{a} / \mathrm{b}$ polymorphisms were found to be $0.94,0.90$ and 0.25 , respectively. $P$ values for the control group were estimated to be $0.025,0.001$, and 0.19 , respectively.

As for clinical results, the patients were studied in four main groups: those having mucocutaneous findings, ocular involvement, articular findings, and vascular findings. The number of patients whose other systems were potentially affected by Behçet's disease were not adequate for statistical evaluations and related calculations were not made. When the patient and control groups were compared with all clinical subgroups, any significant difference apart from $-786 \mathrm{~T}>\mathrm{C}$ was not detected. Also, any correlation with pathergy positivity was not found when patients with a positive pathergy reaction and the control group were compared. P values for the Glu298Asp, $-786 \mathrm{~T}>\mathrm{C}$, and intron $4 \mathrm{a} / \mathrm{b}$ polymorphisms were estimated to be $0.41,0.006,0.41$ for pathergy positivity; $0.15,0.001$, 0.6 for mucocutaneous findings; $0.25,<0.001,0.6$ for ocular; 0.18, 0.005, 0.48 for articular; and 0.39, 0.004, 0.64 for vascular involvement, respectively.

In comparisons performed both within the patient group and the controls with respect to familial history, no significant differences, aside from alterations in $-786 \mathrm{~T}>\mathrm{C}$, were observed. This supports the results of the comparison between the patient and control

\begin{tabular}{|lccccc|}
\hline \multicolumn{3}{l}{ Table 2. Genotypes and allele frequencies } & & \\
\hline Genotypes and allele frequencies & \multicolumn{2}{l}{ Patient } & & \multicolumn{2}{c|}{ Control } \\
\cline { 2 - 3 } \cline { 5 - 6 } & $\mathrm{n}$ & $\%$ & & $\mathrm{n}$ & $\%$ \\
\hline Glu298Asp & 65 & 41.9 & & 26 & 26.5 \\
GG & 80 & 51.6 & 59 & 60.2 \\
GT & 10 & 6.5 & 13 & 13.3 \\
TT & 210 & 67.7 & 111 & 56.6 \\
G & 100 & 32.3 & 85 & 43.4 \\
T & & & & \\
-786T $>$ C & 65 & 41.9 & 65 & 71.4 \\
TT & 70 & 45.2 & 17 & 18.7 \\
TC & 20 & 12.9 & 9 & 9.9 \\
CC & 200 & 64.5 & 147 & 80.8 \\
T & 110 & 35.5 & 35 & 19.2 \\
C & & & & \\
Intron 4 a/b & 107 & 69 & 66 & 67.3 \\
bb & 47 & 30.3 & 28 & 28.6 \\
ba & 1 & 0.6 & 4 & 4.1 \\
aa & 261 & 84.2 & 160 & 81.6 \\
b & 49 & 15.8 & 36 & 18.4 \\
a & & & & \\
\hline
\end{tabular}


groups without the inclusion of clinical findings and familial history. No additional significant changes were observed. $\mathrm{P}$ values were found to be $0.31,0.02$ and 0.27 for the Glu298Asp, $-786 \mathrm{~T}>\mathrm{C}$, and intron $4 \mathrm{a} / \mathrm{b}$ polymorphisms, respectively.

\section{DISCUSSION}

Nitric oxide is a versatile molecule involved in many pathways. It is released from the vascular endothelium leading to a relaxation of the vascular smooth muscle and to the inhibition of in situ platelet aggregation along with the proliferation of smooth muscle cells. Any abnormality in this system results in endothelial dysfunction. Additionally, some literature reviews have reported reduced enzymatic activity because of some eNOS polymorphisms. ${ }^{[23,24]}$ Endothelial dysfunction has been demonstrated in Behçet's disease. ${ }^{[17,18]}$ A group of studies has reported decreased serum NO levels in patients with Behçet's disease. ${ }^{[12,16]}$ In light of all these studies, eNOS polymorphisms might play a role in the pathogenesis of Behçet's disease.

The first study conducted assuming the role of the eNOS gene in Behçet's disease was from Salvarani et al., ${ }^{[14]}$ Seventy-three patients and 135 controls took part in this study in 2002 in which the Glu298Asp and VNTR polymorphisms in intron 4 were examined. For the Glu298Asp polymorphism, both the heterozygous and homozygous mutant genotype and the so-called $\mathrm{T}$ allele were found to be in excess in patients with Behçet's disease. On the other hand, no significant difference was detected for the intron $4 \mathrm{a} / \mathrm{b}$ polymorphism, and there was also no correlation found between this polymorphism and clinical symptoms. The investigators stated that Glu298Asp is related to the disease independent from the existence of HLA-B51.

In 2003, Kim et al. ${ }^{[28]}$ repeated an identical study on 65 patients with Behçet's disease, 27 cases with vasculitic rheumatism, and 80 control subjects and obtained similar results. In other words, the Glu298Asp polymorphism is related to the disease, but it is not associated with the patient's age at onset of the disease or severity of clinical manifestations.

Another study pertaining to the subject was done by Karasneh et al. ${ }^{[26]}$ from the Great Britain on 193 Turkish patients with Behçet's disease and 108 controls. In this study, they looked at the same three polymorphisms that were investigated in our study, and interesting results were obtained. Contrary to the other two studies, the investigators could not find any correlation with Glu298Asp and detected significantly higher levels of the ' $b$ ' allele in patients with the intron $4 \mathrm{a} / \mathrm{b}$ polymorphisms. In addition, they did not observe any difference regarding -786T $>C$. However, when patients with a positive familial history were evaluated, a higher frequency of T alleles in patients with Behçet's disease was found. These findings were then discussed in relationship to controversial studies in the literature. It was suggested that polymorphisms reduced or had no effect on enzymatic activities, but it was very difficult to firmly state the main polymorphism controlling this phenomenon. The authors suggested that the intron $4 \mathrm{VNTR}^{\star} \mathrm{b}$ and $-786^{\star} \mathrm{T}$ haplotypes might harbor this polymorphism.

In 2006, Kara et al. ${ }^{[27]}$ and Oksel et al. ${ }^{[29]}$ published studies on the subject from Turkey. In these studies only the Glu298Asp polymorphism was investigated. Kara et al. ${ }^{[27]}$ did not find any correlation between the disease and the polymorphism, but Oksel et al. ${ }^{[29]}$ declared the opposite and found higher frequencies of the $\mathrm{T}$ allele in the patient group.

The most recent study is from Tunisia in which again only the Glu298Asp polymorphism was investigated, and they suggest that the Glu298Asp polymorphism is associated with Behçet's disease susceptibility as well as skin lesions. ${ }^{[30]}$

In our study, distribution of the intron $4 \mathrm{a} / \mathrm{b}$ polymorphism did not differ within either the patient or control group. This finding is in compliance with the results found in the studies conducted by Salvarani et al. ${ }^{[14]}$ and Kim et al. ${ }^{[28]}$ Although Karasneh et al. ${ }^{[26]}$ reported higher incidences for the $\mathrm{b}$ allele in their patients, since they could not assert any correlation between the disease and this allele per se, our results do not contradict their outcomes.

In contrary to the Karasneh et al. ${ }^{[26]}$ study, which was the only study other than ours to investigate the $-786 \mathrm{~T}>\mathrm{C}$ polymorphism in Behçet's disease, the higher frequency of the T allele and TT genotype that we detected in our control group does not contradict our basic rationale and logic since this polymorphism is known to be a promoter region mutation that reduces enzymatic activity, and it is related to many other predominantly cardiovascular diseases. Therefore, our assumption holds true. The outcomes of our study carry similar implications. Moreover, Karasneh et al. ${ }^{[26]}$ reported higher frequencies for the $\mathrm{T}$ allele in patients with a positive familial history and could not state definitively that this allele is related to the disease, although it might be inferred. 
The higher frequencies of the GG genotype and $G$ allele in the Glu298Asp polymorphism we found in our patients seem to differ from the results of other studies. Since some studies have suggested that the 298Asp allele does not change its enzymatic activity or reduce this activity by enhancing mRNA trimming, our results can not be disregarded from the perspective of the enzymatic mechanism. ${ }^{[20,23]}$ By accepting both assumptions, our result apparently will not influence NO levels in our patient group.

In conclusion, in our study, irrespective of familial history and clinical findings, the $-786 \mathrm{~T}>\mathrm{C}$ polymorphism was found to be correlated with Behçet's disease, and the $C$ allele was found to be more prevalent in patients with Behçet's disease. In addition, the intron $4 \mathrm{a} / \mathrm{b}$ and Glu298Asp polymorphisms were not detected to be directly related to the disease.

In studies performed for eNOS polymorphisms in other diseases, literature reports have suggested that diverse results could be obtained even within the same population. In the present study, a similar phenomenon has been encountered. This outcome emphasizes more predominantly the impact of the eNOS gene expression and other potential genetic and environmental factors in the mechanism of action. Therefore, more comprehensive and controlled further studies are required on this subject.

\section{Declaration of conflicting interests}

The authors declared no conflicts of interest with respect to the authorship and/or publication of this article.

\section{Funding}

This study was supported by Ankara University Scientific Research Projects.

\section{REFERENCES}

1. Marshall SE. Behçet's disease. Best Pract Res Clin Rheumatol 2004;18:291-311.

2. Yurdakul S, Yazici H. Behçet's syndrome. Best Pract Res Clin Rheumatol 2008;22:793-809.

3. Sakane T, Takeno M, Suzuki N, Inaba G. Behçet's disease. N Engl J Med 1999;341:1284-91.

4. Onder M, Gürer MA. Behçet's disease: an enigmatic vasculitis. Clin Dermatol 1999;17:571-6.

5. Hegab S, Al-Mutawa S. Immunopathogenesis of Behçet's disease. Clin Immunol 2000;96:174-86.

6. Hirohata S, Kikuchi H. Behçet's disease. Arthritis Res Ther 2003;5:139-46.
7. Verity DH, Wallace GR, Vaughan RW, Stanford MR. Behçet's disease: from Hippocrates to the third millennium. Br J Ophthalmol 2003;87:1175-83.

8. Zouboulis CC, May T. Pathogenesis of AdamantiadesBehçet's disease. Med Microbiol Immunol 2003; 192:149-55.

9. Eksioglu-Demiralp E, Direskeneli H, Kibaroglu A, Yavuz S, Ergun T, Akoglu T. Neutrophil activation in Behçet's disease. Clin Exp Rheumatol 2001;19:S19-24.

10. Takeno M, Kariyone A, Yamashita N, Takiguchi $M$, Mizushima Y, Kaneoka $\mathrm{H}$, et al. Excessive function of peripheral blood neutrophils from patients with Behçet's disease and from HLA-B51 transgenic mice. Arthritis Rheum 1995;38:426-33.

11. Sensi A, Gavioli R, Spisani S, Balboni A, Melchiorri L, Menicucci A, et al. HLA B51 antigen associated with neutrophil hyper-reactivity. Dis Markers 1991;9:327-31.

12. Chambers JC, Haskard DO, Kooner JS. Vascular endothelial function and oxidative stress mechanisms in patients with Behçet's syndrome. J Am Coll Cardiol 2001;37:517-20.

13. Freitas JP, Filipe P, Yousefi A, Emerit I, Guerra Rodrigo F. Oxidative stress in Adamantiades-Behçet's disease. Dermatology 1998;197:343-8.

14. Salvarani C, Boiardi L, Casali B, Olivieri I, Ciancio G, Cantini F, et al. Endothelial nitric oxide synthase gene polymorphisms in Behçet's disease. J Rheumatol 2002;29:535-40.

15. Evereklioglu C, Turkoz Y, Er H, Inaloz HS, Ozbek E, Cekmen M. Increased nitric oxide production in patients with Behçet's disease: is it a new activity marker? J Am Acad Dermatol 2002;46:50-4.

16. Orem A, Vanizor B, Cimşit G, Kiran E, Değer O, Malkoç M. Decreased nitric oxide production in patients with Behçet's disease. Dermatology 1999;198:33-6.

17. Schmitz-Huebner U, Knop J. Evidence for an endothelial cell dysfunction in association with Behçet's disease. Thromb Res 1984;34:277-85.

18. Haznedaroglu IC, Ozcebe OI, Ozdemir O, Celik I, Dündar SV, Kirazli S. Impaired haemostatic kinetics and endothelial function in Behçet's disease. J Intern Med 1996;240:181-7.

19. Wang XL, Mahaney MC, Sim AS, Wang J, Wang J, Blangero J, et al. Genetic contribution of the endothelial constitutive nitric oxide synthase gene to plasma nitric oxide levels. Arterioscler Thromb Vasc Biol 1997; 17:3147-53.

20. Tsukada T, Yokoyama K, Arai T, Takemoto F, Hara S, Yamada A, et al. Evidence of association of the ecNOS gene polymorphism with plasma NO metabolite levels in humans. Biochem Biophys Res Commun 1998;245:190-3.

21. Wang XL, Sim AS, Wang MX, Murrell GA, Trudinger B, Wang J. Genotype dependent and cigarette specific effects on endothelial nitric oxide synthase gene expression and enzyme activity. FEBS Lett 2000;471:45-50. 
22. Alderton WK, Cooper CE, Knowles RG. Nitric oxide synthases: structure, function and inhibition. Biochem J 2001;357:593-615.

23. Li H, Wallerath $\mathrm{T}$, Förstermann U. Physiological mechanisms regulating the expression of endothelial-type NO synthase. Nitric Oxide 2002;7:132-47.

24. Albrecht EW, Stegeman CA, Heeringa P, Henning RH, van Goor H. Protective role of endothelial nitric oxide synthase. J Pathol 2003;199:8-17.

25. Wattanapitayakul SK, Mihm MJ, Young AP, Bauer JA. Therapeutic implications of human endothelial nitric oxide synthase gene polymorphism. Trends Pharmacol Sci 2001;22:361-8.

26. Karasneh JA, Hajeer AH, Silman A, Worthington J, Ollier WE, Gul A. Polymorphisms in the endothelial nitric oxide synthase gene are associated with Behçet's disease. Rheumatology (Oxford) 2005;44:614-7.
27. Kara N, Senturk N, Gunes SO, Bagci H, Yigit S, Turanli AY. Lack of evidence for association between endothelial nitric oxide synthase gene polymorphism (glu298asp) with Behçet's disease in the Turkish population. Arch Dermatol Res 2006;297:468-71.

28. Kim JU, Chang HK, Lee SS, Kim JW, Kim KT, Lee SW, et al. Endothelial nitric oxide synthase gene polymorphisms in Behçet's disease and rheumatic diseases with vasculitis. Ann Rheum Dis 2003;62:1083-7.

29. Oksel F, Keser G, Ozmen M, Aksu K, Kitapcioglu G, Berdeli A, et al. Endothelial nitric oxide synthase gene Glu298Asp polymorphism is associated with Behçet's disease. Clin Exp Rheumatol 2006;24:S79-82.

30. Ben Dhifallah I, Houman H, Khanfir M, Hamzaoui K. Endothelial nitric oxide synthase gene polymorphism is associated with Behçet's disease in Tunisian population. Hum Immunol 2008;69:661-5. 